
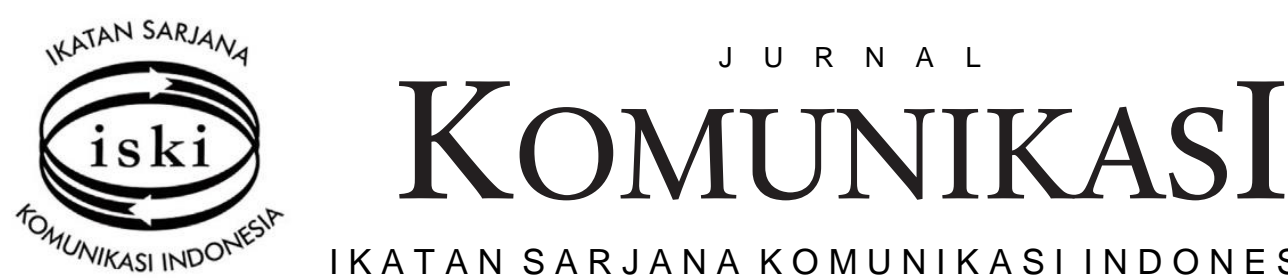

E-ISSN: 2503-0795

P-ISSN: 2548-8740

IKATAN SARJANAKOMUNIKASI INDONESIA

\title{
The Management of Negotiation Process in the Animal Welfare Dispute in Bandung Zoo
}

\author{
http://dx.doi.org/10.25008/jkiski.v3i2.149
}

\author{
Herlina Agustin $^{1 *}$, Rinda Aunillah Sirait ${ }^{2}$, Dandi Supriadi ${ }^{3}$ \\ ${ }^{1,2,3}$ Faculty of Communication Sciences - University of Padjadjaran \\ Jl. Raya Bandung Sumedang Km. 21, Jatinangor, West Java - Indonesia \\ *Correspondent author: h.agustin@unpad.ac.id
}

Submitted: 05 August 2018, Revised: 24 December 2018, Accepted: 27 December 2018

Accredited by Kemristekdikti No. 30/E/KPT/2018

\begin{abstract}
Management of conflict and negotiation played an important role in solving a dispute. Both actions were not simple tasks in resolving conflicts since different points of view usually involve. This was what happened in the dispute of animal welfare issue between Bandung Zoo and Scorpion Wildlife Foundation. The dispute that became the focus of this article related to the accusation raised by the Scorpion Wildlife Foundation towards the Bandung Zoo in terms of animal welfare abandonment. The conflict between the two organizations has increased because the zoo did not accept the allegations and intended to bring the foundation to a legal court for the reason of defamation. This article looked at the use of the management of conflict and the negotiation to resolve this conflict by the Agency of Natural Resources of West Java as facilitator. The study used constructive case study method to chronologically construct the conflict and the use of negotiation. The results showed that the facilitator dominated the negotiation process, while the conflicting parties have not had any agreement to resolve the problem. The condition had a potential to be invalid any time if the dispute was not completely resolved.
\end{abstract}

Keywords: animal welfare, Bandung Zoo, conflict management and negotiation.

Copyright (C) 2018 Ikatan Sarjana Komunikasi Indonesia. All rights reserved

\section{Introduction}

As a public conservation institution, Kebun Binatang Bandung $(K B B)$ or Bandung Zoo was required to warrant the prosperity of its animals (Puspitasari, 2016; Margaretta, 2013; Madya, 2018). Ideally, zoo management, including animal care, should involve relevant stakeholders like Balai Konservasi Sumber Daya Alam (BKSDA) or the Agency of Natural Resource Conservation, nongovernment organizations and civil communities that concerned about animal welfare. The involvement of the stakeholders has been stipulated in the Regulation of the Ministry of Forestry No. $31 / 2012$ on Conservation Institutions.

A problem occurred when a video showing the condition of Kardit, one of the Bandung Zoo's sun bear collections, was published on social media in mid-January 2017. The video showed the bear eating its own feces. Another scene showed a starving condition in which a bear asking zoo visitors for food. This publication became viral and raised major public criticism of the zoo. Even, more criticisms were expressed by international communities, which made the problem major news in international mass media. 
Scorpion Wildlife Foundation, an NGO that focused on animal welfare monitoring, claimed itself to be the one that recorded and uploaded the video. Marison Guciano, a senior investigator of the foundation, stated that sun bears in the zoo were unnaturally behaving like pacing back and forth, eating their own feces and continuously agitating their body. These behaviors were symptoms of a stressed animal. It meant that those bears were depressed and needed more concerns of many parties (Viani, 2017).

Guciano suggested that one of the causal factors of the depression was the environmental condition of the cage, which was very different from their original habitat. Moreover, the limited space in the zoo forced it to put four bears in a cage, while sun bears were usually solitary in nature.

Sun bears lived in tropical forest, but we could see that they were put in small and narrow cages. Even, some cages did not haven any tree inside to climb, so those bears could not perform their activities as they usually did in the wild, Guciano said (Viani, 2017).

The foundation has asked an independent vet to check the bears' health condition, including not only their physical, but also psychological condition. Guciano suggested that there should be a comparative report of other zoos since the zoo was a member of Perkumpulan Kebun Binatang Seluruh Indonesia (PKBSI) or Association of Indonesian Zoos. The conclusion of its evaluation was that the zoo has failed to meet animal welfare requirements for the animals under its responsibility.

The animal welfare referred to five internationally ratified animal welfare standards. The foundation considered the zoo as neglectful, which led to the poor conditions as shown in Kardit's video.

The polemic became worse when the foundation officially asked Kementerian Lingkungan Hidup dan Kehutanan (KLHK) or the Ministry of Environment and Forestry of the Republic of Indonesia to close the zoo down based on the evaluation that put the zoo into the category of incapable conservation institution that was unable to properly maintain its animals. It made the indictment because of the deadlocked communication with the zoo management. It claimed that it has long asked the zoo and the Mayor of Bandung for the closing of the zoo. Unfortunately, it was ignored because it has addressed its demand for the closing of the zoo to inappropriate parties. It should address the demand to the appropriate institution instead, which was the Ministry of Environment and Forestry of the Republic of Indonesia. Subsequently, it created a petition through Change.org to support its indictment against the ministry.

Despite the public pressures, the zoo tended to avoid the polemic after it claimed in a press conference that the accusation of the foundation was inaccurate. The head of the zoo, Romli Sundara Bratakusumah, could not be confirmed for illness reason. Any possible communication has been tried with Sudaryo, a public relation officer of the zoo and failed. It became an obstacle to resume the closing issue since all strategic decision should be approved by the head of the zoo. The response of the zoo raised more conflict, which led to the need for a mediator to negotiate the best solution.

Concerning with the controversial issue, the article discussed the results of a study on the negotiation process in resolving the zoo closure polemic. There were many steps and meetings regarding the issue. However, narrowing the research focus the study looked at the first joint meeting on January $28^{\text {th }}, 2017$, which initiated by the head of Regional BKSDA of West Java, Sustyo Iriyono. Besides the zoo and the foundation, the meeting also involved PKBSI Committee, KLHK representatives and Profauna, an environmental NGO that frequently conducted zoo monitoring in many sites, including the zoo.

\section{Theoretical Frameworks}

The study used some concepts and theories to analyze the findings. One of them was the concept of five freedoms that was promoted by the Farm and Animal Welfare Committee (FAWC). The organization was established by British government in 1979 to replace the Farm Animal Welfare Advisory Committee (FAWAC). It believed that an animal, regardless of the place where it was put (on farm, in transit, at market or in a slaughtering place) should be treated in ideal states of welfare. It considered that the ideal welfare consisted of five freedoms (FAWC, 2012).

The concept supported following freedoms: 1) freedom from hunger and thirst, 2) freedom from discomfort, 3) freedom from pain, injury or disease, 4) freedom to express normal behavior, and 5) freedom from fear and distress.

The concept of the five freedoms was inspired by the 1965's Brambell Report, a report of farm animals in livestock husbandry systems in London. In the original report, it was stated that the 
animals should have freedom to stand up, lie down, turn around, groom themselves and stretch their limbs. The version of the list of freedoms was recognized as Brambell's five freedoms.

Although this concept was established and has been applied in the UK environmentalists and animal watchers in the world generally agreed on the concept. They urged all conservation institutions, including zoos, to use the list of freedoms as a welfare guidance.

Another useful theory in the study was conflict social theory by Lewis Coser (Haryanto, 2016). Coser looked at the conflict as a disruptive or dysfunctional problem that could be potentially solved by applying sociological expertise. Furthermore, he (Haryanto, 2016: 52-54) concluded that: 1) Conflict tended to increase social adjustment and to maintain group's boundaries, 2) Conflict occurred when there was a demand for particular reward of some works, 3) The tighter was the stratification system, the fewer was the tolerance and the higher was the group's participation, the more potentials they had in creating conflict, 4) The type of problem that created conflict usually related to common people's legitimation and involved basic assumption disagreement, and 5) The combination of the above factors would create functional conflict for a social system.

In environment related conflicts, the problems that usually occurred were those related to the perception collision between business and conservation. Dealing with the clash required communication openness and understanding of environmental conservation. It was in the context that persuasive communication was essential to increase the equality of perception and it was necessary to involve hard negotiation process. It was the reason of using negotiation theory in the study. In negotiation theory, as Herb Cohen (1982) deliberated, possessing the power, determining the time frame and using the right information were significant additional factors that would help in solving problems.

According to the theory, power was something that could improve the ability to solve problems. For instance, if we had a good bargaining position, we would have more power in negotiation. The power could also come from the legitimation of the level of expertise, empathy, determination, attitude and the skill of persuasion. Above all, Cohen stated that the power would be earned if the negotiator was willing to take countable risks (Cohen, 1982: 69-73).
Determining the time was the second significant factor. The resolution of a problem usually involved time frame setting, such as deadlines. The negotiator should be able to control the decision and to make the decision of the deadlines a convention, meaning that it was agreed by all of the parties involved (Cohen: 91-100).

The quality of acquired information was the third crucial factor. One with better information would have a better position in the negotiation. Not only in the acquired information was Cohen also interested in nonverbal message that usually occurred during the conversation. The opponent's responds, questions, even body languages could transmit valuable information (Cohen 1982: 101118).

Most of the negotiation was usually considered as rivalries or competitions. Each side then tried to reach better end based on a convention. However, Cohen stated that the situation was not necessarily like that. There were times when people needed to shift from competitive mode to collaboration, to achieve win-win scenario. Doing it, we needed a different way of thinking and negotiation style (Cohen, 1982: 78-120) in which all of the parties involved should build mutual trust, retrieved the commitment and dealt with the enemies.

\section{Material and Methodology}

The study used constructive case study method. The method was used to investigate the construction of evolving meanings during the polemic. It enabled the study to chronologically explore the conflict and to observe the use of negotiation in a conflict management.

It was based on the formulation of Robert E. Stake who developed three types of case studies (Stake, 2005). The first one was named intrinsic case study and useful to understand a specific case with special uniqueness. The second one was called instrumental case study, which used a particular case related to the specific issue to create an understanding or to generalize a broader concept. The third one was actually a further developed form of the second type, which used more than one case. It was called a collective or multiple case studies, which referred to a study of a number of cases to examine one major issue.

The study looked at a particular case, which was the conflict between the Scorpion Wildlife Foundation and the Bandung Zoo regarding the closure of the zoo. It was to investigate more about 
conflict management related to environmental issues. Regarding the objective of this study, the most appropriate model of the case study was the second one, which was the intrinsic case study. It was considered to be the most relevant because the study looked only a case as a picture to explain a bigger concept.

For accurate findings, the study collected relevant data and information using direct observation and interviews. The observation was done on site during the meeting process. The interviews were organized after the meeting with relevant parties, including BKSDA of West Java's representative who acted as mediator in a neutral position.

\section{Results and Discussion}

The initial joint meeting on January $28^{\text {th }}$, 2017, as the main subject of the study, was a sensitive and emotional event involving many interests. It was clearly observed in the observation that all of the parties involved had their own perspective and the debate was hard to be resolved. This was the main factor of the continuous debate about the zoo closure and the dispute of animal welfare.

In the meeting the zoo management insisted that its side has been abused by the allegation of the foundation. Sudaryo refused the accusation about the zoo management's reclusive attitude and the unwillingness to resolve the problematic issue. The zoo considered that the foundation has never directly contacted the management, and the image capturing and video recording inside the zoo's location were regarded as illegal actions because they were done without any permission. The timing of documentation also raised a problem because the viral video was taken in May 2016. The zoo claimed that the situation at the moment was very different and better. It was not fair that the foundation used the recording to represent current condition.

It was an old video. Kardit's condition now is much better, thanks to a good treatment by the management, assisted by special vets from Taman Safari Indonesia. The location of the cage is also different. Kardit has been moved to the bear's section in the front area, not in the middle area as shown on the video. The crucial thing is that we have already fixed the management (Sudaryo, cited from the meeting).
Regarding the news about starvation of the bears in the zoo that subsequently raised the demand for the zoo closure, the zoo and PKBSI declined the allegation. Tony Sumampauw, the head of the PKBSI, reminded everyone in the meeting of the old statement of former Environment Minister Emil Salim. Mr. Emil Salim issued a regulation that forbad any effort to change the function of zoos that have been established in the Dutch colonialism era. It included the Bandung zoo, which has been established since 1930.

The responses of the zoo and the PKBSI were rejected by the foundation, claiming that there was not any significant change in the condition in the period of May 2016 to the present, especially the condition of the bears. Guciano said that he personally observed the bear's condition in early January 2017 and witnessed no noticeable change.

We did see changes, but not significant. Especially about cages, the condition is the same from the old time until now. The water is dirty, and we saw four bears were put inside a small cage. As a result, there was a competition for food, and the weak will be eliminated (Guciano, cited from the meeting).

Guciano asked the PKBSI to involve in the process of collecting evidence. In that occasion, the foundation would bring independent vets and sun bear experts from international conservation institutions.

Meanwhile, as the mediator of the meeting, the $B K S D A$ responded the issue by making a policy to send a special team to the zoo in order to collect more actual evidence. However, the BKSDA expressed its intention to avoid the closure. Sustyo Iriyono considered that there was still good will of many parties to improve the zoo's condition and hence the closure would be the last option. Iriyono referred to the previous incident in Surabaya when the local zoo was forced to close its operation because of similar issue. Therefore, he expressed his disagreement of the closure of the zoo.

Nevertheless, the BKSDA did not have any authority to close the zoo or to abrogate the conservation permit. It was only the Ministry of Forestry and Environment that had the authority to close it. The only action the BKSDA might do was to collect the evidence and related information for the ministry's consideration. The meeting and the plan to send a special team to the zoo were actually some of the ways to collect evidence for the ministry. 
It was observed that the problematic situation between the zoo and the foundation was the result of information uncertainty. This ambiguity worsened because of the unclear communication among the parties concerned. The reclusive attitude of the zoo became the main reason of the foundation to organize demonstration, to publish the video and to distribute the petition through Change.org website.

Therefore, it could be interpreted that the $B K S D A$ has been applying the theory of negotiation to manage the conflict between the two parties. The three elements of negotiation, including power, time and information as described by Cohen, were used by Iriyono as the mediator to solve the deadlock situation.

In the negotiation process Iriyono used his power to control the conversation. It was clearly observed that in the meeting his power was legitimated by all of the parties involved due to his position as the Head of Regional BKSDA of West Java. Moreover, everybody who attended the meeting has recognized his capability and experience in resolving major conflict related to environmental cases. The valuable backgrounds were strengthened by Iriyono's ability to use his appropriate gestures, including his voice tone and body languages, which convinced everyone about his supremacy. He also declared his position in the neutral zone by not supporting the demand of the foundation for closing the zoo and convinced all of the parties that the zoo still had a good will in making the zoo a better place.

In terms of time frame Iriyono seemed to be aware that the conflict would not be resolved without any clear time limitation, concerning that the conflict itself has been going on for a long time. It was observed that he has urged the resolution by setting up a strict deadline. The meeting has decided to give the zoo three months from the time of the meeting to restore the zoo maintenance, to improve the procedure of animal welfare protection, and to publish the information related to the zoo condition. It was also decided that the $B K S D A$ supported by environmental NGOs would conduct monthly monitoring until the condition was better. Setting up the deadline might be interpreted that he tried to draw serious concerns of the conflicted parties.

The last element was information. In the negotiation Iriyono used his advanced knowledge of resolving the dispute in an environmental case. He tried to convince the conflicting parties that there were regulations to solve the dispute. Theoretically, this miscommunication should not necessarily happen since the existing regulations actually provided both parties with a good opportunity to interact and even to collaborate. The regulations that enabled a communication sphere and transparency included the Act No. 14/2008 on Public Information Disclosure and the Act No. 32/2009 on Environment Protection and Management. The acts described public rights to acquire information of public institution regarding environmental conservation. In other words, these regulations have provided people with opportunities to communicate and negotiate. Using the existing regulations Iriyono has brought the negotiation process into the next step of resolution.

Based on his actions it could be seen that Iriyono tried to create a win-win scenario. However, his attitude during the meeting might be considered as too dominant. Although his power was legitimate, his attitude might attract a negative response. Instead of building the trust, as one of the strategies to implement win-win scenario, he tended to create resistance because of his authoritarian style.

It could be the reason why the zoo and the foundation did not take the decision for granted and still needed more meetings before they accepted the resolution agreement. Although Iriyono sucessfully led the meeting with his style, it could be seen that either the zoo or the foundation has not reached a high level of trust. Nevertheless, the strategy Iriyono used as a mediator has brought the conflict into a better state.

\section{Conclusion}

In many cases, the ideology of conservation was considered as complicated and hard to understand. The assumption resulted in a situation in which people had less concern about an issue and ignored its basic philosophy. Those who did not comprehend the philosophy of conservation and environmental preservation would take anything for granted, which was offered by business parties.

In the capitalistic perspective zoos have been using animals as their commodity. For the reason of providing education about wildlife, animals were kept in cages for public display, which were frequently very different from the real habitat. The zoos' supporters agreed about the commercialization because the institution needed huge finance for maintenance and to gain revenue from the visitors at the same time. The idea became a controversy, especially amongst animal freedom 
supporters who tried to optimize animal function in an ecological system.

The conflict discussed in the article occurred because the demand of the foundation for information disclosure was not fulfilled by the zoo. It became communication obstacle that resulted in misunderstanding. It was escalated since the foundation tried to draw people's attention by uploading controversial videos about sun bears' condition in the zoo. Therefore, a neutral mediating party was required to lower the high tense. In this case the $B K S D A$ tried to facilitate the negotiation process between the two organizations.

The study showed that conflicts could be well-resolved using a perfect communication strategy. The right stakeholders, the communication audience, the transparency in communication sphere, and negotiation process could reduce the potential of dead-locked communication channels. The Head of the BKSDA of West Java has been using negotiation strategy, though at the end he should use his power and authority to decide the final resolution.

The results of the initial negotiation had the potential to resolve the disagreement between the zoo and the foundation and to overcome the issue of animal welfare and environmental preservation in the zoo. However, it was not the end of the problem. The government and relevant authorities had to watch the zoo consistently and objectively.

\section{Acknowledgment}

The article was a part of our concern in the Centre of Environmental Communication, the Faculty of Communication Sciences, Padjadjaran University. It was our great pleasure to have the opportunity to thank our colleagues from Balai Konservasi Sumber Daya Alam dan Ekosistemnya $(B K S D A)$ or the Agency of Natural Resource Conservation, who have maintained strong relationship with our institution and providing us with information related to environmental issues. We also would like to express our special gratitude to Mr. Sustyo Iriyono, the Head of the BKSDA of the Regional Office of West Java, for giving us opportunity to conduct the observation in the negotiation process between the Bandung Zoo and the Scorpion Wildlife Foundation. Finally, we would like to express our appreciation to the Faculty of Communication Sciences, Padjadjaran University that gave their prime supports to the dissemination of our studies and this publication in international.

\section{References}

Cohen, Herb, (1982). You can negotiate anything. New York, NY: Bantam Books.

Cox, Robert. (2013). Environmental communication and the public sphere. $3^{\text {rd }}$ ed. CA: Sage Publication Inc.

FAWC. (2017). "Farm Animal Welfare Council: Five Freedoms". The National Archive. 10 Oct 2012.

http://webarchive.nationalarchives.gov.uk/ 20121010012427/http://www.fawc.org.uk/free doms.htm. Accessed 18 Aug 2017.

Haryanto, Sindung. (2016) The Spectrum of Social Theory: From Classic to

Postmodern (Spektrum teori sosial: Ddari Klasik Hingga Postmodern). Yogyakarta: Ar-Ruzz Media.

Madya, Citra Dwi. (2018). Pengembangan Media Interpretasi Nonpersonal untuk Mendukung Pariwisata Edukasi pada Area Aves di Kebun Binatang Bandung, Jurnal Manajemen Resort \& Leisure. Vol 15(1): 59-73.

Margaretta, Florensia, Christina Wirawan. (2013). Usulan Peningkatan Kualitas Pelayanan di Kebon Binatang Bandung (Service Quality Improvement Proposal at Bandung Zoo). Jurnal Integra. Vol 3(1): 43-57.

Puspitasari, Anggita, Burhanuddin Masya'ud, Tutut Sumarminto. (2016). Nilai Kontribusi Kebon Binatang terhadap Konservasi Satwa, Sosial Ekonomi, dan Lingkungan Fisik: Studi Kasus Kebon Binatang Bandung (Contribution Value of Zoo to the Wild Animal Conservation, Socio-economic, and Physical Environment: Case Study in Bandung Zoo). Media Konservasi Vol 21(2): 116-124.

Regan, Tom. (2001). Defending Animal Rights. Illinois: The Board of Trustees of the University of Illinois.

Stake, R.E. (2005), Case Studies in N. K. Denzin \& Y. S. Lincoln (Eds.), The Sage Handbook of Qualitative Research. Thousand Oaks: Sage Publications Inc.

Viani, Devi. (2017). Scorpion Foundation: Sun Bears in the Bandung Zoo Are

Stressful (Beruang Madu di Kebun Binatang Bandung Alami Stres). PRFMNews 25 Jan 2017. 